\title{
Structure Revision and Syntheses of Epohelmins A and B
}

\author{
Barry B. Snider*, Xiaolei Gao
}

Department of Chemistry, MS 015, Brandeis University, Waltham, Massachusetts 02454-9110.

\section{Supporting Material}

Experimental Procedures

S2-S1 1

Comparison of the Spectral Data Reported for Epohelmin A with Those of 11 ...S12

NOE Data for Epohelmin A Model 11 and Epohelmin B Model 16 S13-S14

Copies of ${ }^{1} \mathrm{H}$ and ${ }^{13} \mathrm{C}$ NMR Spectra.. S15-S52 


\section{Experimental Section}

General Procedures. NMR spectra were recorded at $400 \mathrm{MHz}$ in $\mathrm{CDCl}_{3}$ unless otherwise indicated. Chemical shifts are reported in $\delta$, coupling constants in Hz, and IR spectra in $\mathrm{cm}^{-1}$.

\section{(1R)-1-[(S)-N-Benzyloxycarbonylpyrrolidin-2-yl]-1-hydroxy-3-octanone (10).}

Lithium diisopropylamide was prepared from diisopropylamine $(904 \mu \mathrm{L}, 6.45 \mathrm{mmol})$ and $n$-BuLi (1.6 $\mathrm{M}$ in hexanes, $3.85 \mathrm{~mL}, 6.16 \mathrm{mmol})$ in THF $(48 \mathrm{~mL})$ at $0{ }^{\circ} \mathrm{C}$. This solution was cooled to $-78{ }^{\circ} \mathrm{C}$ and treated with 2-heptanone $(818 \mu \mathrm{L}, 5.87 \mathrm{mmol})$ in $10 \mathrm{~mL}$ of dry THF by syringe pump over $40 \mathrm{~min}$. The reaction mixture was stirred for another $30 \mathrm{~min}$ at $-78{ }^{\circ} \mathrm{C}$ and treated with a solution of benzyl (2S)-2-formyl-1-pyrrolidinecarboxylate $(\mathbf{9})^{7}(1.14 \mathrm{~g}, 4.89 \mathrm{mmol})$ in THF (10 $\mathrm{mL}$ ) dropwise. The mixture was stirred at $-78{ }^{\circ} \mathrm{C}$ for $2 \mathrm{~h}$, and quenched with acetic acid (840 $\mu \mathrm{L}, 14.67 \mathrm{mmol})$ in ether $(15 \mathrm{~mL})$. The resulting mixture was diluted with EtOAc $(400 \mathrm{~mL})$, washed with saturated aqueous $\mathrm{NaHCO}_{3}$ solution, brine, dried $\left(\mathrm{MgSO}_{4}\right)$, and concentrated to give a yellow oil. Flash chromatography on silica gel (4:1 hexanes/EtOAc) gave 10 (1.62 g, 95\%) as a colorless oil: $[\alpha]^{22}{ }_{\mathrm{D}}-58$ (c 1.02, MeOH); ${ }^{1} \mathrm{H}$ NMR 7.29-7.37 (m, 5), 5.10-5.22 (m, 2), 4.16-4.22 (m, 1), 3.90-4.09 (m, 1), 3.52-3.59 (m, 1), 3.31-3.38 (m, 1), 2.08-2.58 (m, 4), 1.76-1.92 (m, 4), 1.48-1.57 (m, 2), 1.24-1.32 (m, 4), 0.88 (t, 3, J = 7.0); IR 3436, 2956, 1699, 1416, 1358; HRMS (DCI/NH$)$ calcd for $\mathrm{C}_{20} \mathrm{H}_{30} \mathrm{NO}_{4}\left(\mathrm{MH}^{+}\right)$348.2175, found 348.2169.

(1R,3S,7aS)-Hexahydro-3-pentyl-1H-pyrrolizin-1-ol (11). A mixture of 10 (658 mg, $1.90 \mathrm{mmol})$ and $\mathrm{Pd}(\mathrm{OH})_{2}(20 \mathrm{wt} \% \mathrm{Pd}$ on carbon, $50 \mathrm{mg})$ in $\mathrm{MeOH}(50 \mathrm{~mL})$ was degassed, stirred under $\mathrm{H}_{2}$ for $12 \mathrm{~h}$ and filtered through Celite, which was washed with $\mathrm{MeOH}$. The combined filtrate was concentrated to give a yellow oil $(380 \mathrm{mg})$. Flash chromatography on silica gel $\left(\mathrm{CH}_{2} \mathrm{Cl}_{2}, 4: 1 \mathrm{CH}_{2} \mathrm{Cl}_{2} / \mathrm{MeOH}\right.$ then $\left.\mathrm{MeOH}\right)$ gave 11 (264 mg, 71\%) as a colorless oil: $[\alpha]^{22}{ }_{\mathrm{D}}+30$ (c 1.03, MeOH); ${ }^{1} \mathrm{H}$ NMR 3.98 (br, 1, OH), $3.86(\mathrm{ddd}, 1, J=9.2,6.1,6.1), 3.31$ (ddd, 1, $J=6.7$, 6.1, 6.1), $2.90(\mathrm{ddd}, 1, J=11.0,7.0,7.0), 2.62(\mathrm{ddd}, 1, J=11.0,5.5,5.5), 2.52-2.58(\mathrm{~m}, 1), 2.29$ (ddd, $1, J=12.2,6.1,6.1), 1.92(\mathrm{dddd}, 1, J=14.0,7.0,7.0,6.7), 1.70-1.77(\mathrm{~m}, 2), 1.52-1.65(\mathrm{~m}$, 
3), 1.37-1.46 (m, 1), $1.28(\mathrm{~m}, 6), 0.88(\mathrm{t}, 3, J=7.0) ;{ }^{13} \mathrm{C}$ NMR 76.6, 72.0, 65.1, 54.2, 42.3, 36.9, 32.0, 30.1, 26.8, 24.9, 22.6, 14.0; IR 3375, 2926, 1457; HRMS (EI+) calcd for $\mathrm{C}_{12} \mathrm{H}_{23} \mathrm{NO}\left(\mathrm{M}^{+}\right)$ 197.1780, found 197.1777.

The effect of acid on the NMR spectra was determined by adding 1 M HOAc (prepared from $58 \mu \mathrm{L}$ of $\mathrm{HOAc}$ in $1 \mathrm{~mL}$ of $\mathrm{CDCl}_{3}$ ) to the free amine 11 in $\mathrm{CDCl}_{3}$ in $1 \mu \mathrm{L}$ portions until the ${ }^{1} \mathrm{H}$ NMR spectrum didn't change anymore. The spectral data for $\mathbf{1 1} \cdot \mathrm{HOAc}$ follow: ${ }^{1} \mathrm{H}$ NMR 4.14 (br, 1), 4.12 (br, 1), 3.47 (ddd, $1, J=11.6,8.0,8.0), 2.94-2.98$ (m, 2), 2.53 (ddd, 1, $J=12.8$, 6.7, 6.1), 2.22 (dddd, 1, $J=12.7,6.1,6.1,6.1), 2.02(\mathrm{~m}, 3), 1.99$ (s, 3, OAc) 1.87-1.94 (m, 1), 1.78-1.86 (m, 2), 1.30 (m, 6), 0.89 (br, 3); ${ }^{13} \mathrm{C}$ NMR 177.4 (OAc), 74.1, 73.2, 67.2, 52.0, 40.6, 31.39, 31.36, 28.4, 26.5, 24.1, 23.1 (OAc), 22.3, 13.8.

The spectra of $\mathbf{1 1}$ that is $85-90 \%$ protonated with HOAc are identical to those of the ring portion of epohelmin A: ${ }^{1} \mathrm{H}$ NMR 4.18 (br t, 1, $J=6$ ), 4.11 (br t, 1, $J=8$ ), 3.45 (ddd, 1, $J=12.2$, 8.0, 8.0), $2.96(\mathrm{ddd}, 1, J=12.2,6,6), 2.93-2.97(\mathrm{~m}, 1), 2.58(\mathrm{ddd}, 1, J=13.4,6.7,6.7), 2.26$ (dddd, 1, $J=12.7,6.1,6.1,6.1), 2.02-2.07$ (m, 3), 2.02 (s, 3, OAc), 1.85-1.93 (m, 1), 1.79-1.85 (m, 1), 1.73 (dddd, $1, J=12.7,7,7,7), 1.30(\mathrm{~m}, 6), 0.89(\mathrm{t}, 3, J=6.1) ;{ }^{13} \mathrm{C}$ NMR 178 (br, OAc), 74.1, 73.8, 67.3, 51.7, 41.0, 31.54, 31.45, 28.4, 26.6, 24.1, 23.2 (OAc), 22.4, 13.9.

2,3-Dihydro-5-pentyl-1H-pyrrolizine (12). A mixture of 11 (115 mg, $0.33 \mathrm{mmol})$ and $\mathrm{K}_{2} \mathrm{CO}_{3}(229 \mathrm{mg}, 1.66 \mathrm{mmol})$ in $\mathrm{MeOH}(5 \mathrm{~mL})$ was stirred at $25^{\circ} \mathrm{C}$ for $24 \mathrm{~h}$, quenched with $\mathrm{H}_{2} \mathrm{O}$, and extracted with $\mathrm{CH}_{2} \mathrm{Cl}_{2}(3 \times 30 \mathrm{~mL})$. The combined organic layers were washed with brine, dried $\left(\mathrm{Na}_{2} \mathrm{SO}_{4}\right)$, and concentrated to give a yellow oil $(82 \mathrm{mg})$, which was purified by flash chromatography on silica gel (pentane) to give $12(42 \mathrm{mg}, 72 \%)$ as a volatile yellow oil: ${ }^{1} \mathrm{H}$ NMR $5.88(\mathrm{~d}, 1, J=3.4), 5.70(\mathrm{~d}, 1, J=3.4), 3.81(\mathrm{t}, 2, J=7.0), 2.82(\mathrm{t}, 2, J=7.3), 2.51(\mathrm{t}, 2, J$ $=8.0), 2.48(\mathrm{tt}, 2, J=7.3,7.0), 1.59(\mathrm{tt}, 2, J=8.0,7.3), 1.32-1.37(\mathrm{~m}, 4), 0.90(\mathrm{t}, 3, J=7.0) ;{ }^{13} \mathrm{C}$ NMR 135.1, 128.2, 108.1, 97.8, 44.3, 31.6, 28.9, 27.9, 26.8, 24.3, 22.5, 14.0; IR 2928, 1428.

(1R,7aS)-Tetrahydro-1-(2-oxoheptyl)-1H,3H-pyrrolo[1,2-c]oxazol-3-one (14). To a stirred solution of $10(143 \mathrm{mg}, 0.41 \mathrm{mmol})$ in $\mathrm{MeOH}(10 \mathrm{~mL})$ was added $\mathrm{NaBH}_{4}(16 \mathrm{mg}, 0.41$ 
mmol) portionwise at $0{ }^{\circ} \mathrm{C}$. The reaction mixture was stirred at $0{ }^{\circ} \mathrm{C}$ to $25^{\circ} \mathrm{C}$ for $2 \mathrm{~h}$, quenched with $\mathrm{H}_{2} \mathrm{O}$ and concentrated to give $230 \mathrm{mg}$ of the crude diol as a mixture of diastereomers.

To a solution of $190 \mathrm{mg}$ of the crude diol in a mixture of 2-propanol/ $\mathrm{H}_{2} \mathrm{O}(3 \mathrm{~mL} / 3 \mathrm{~mL})$ was added finely powdered $\mathrm{K}_{2} \mathrm{CO}_{3}(236 \mathrm{mg}, 1.71 \mathrm{mmol})$. The reaction mixture was stirred at $70{ }^{\circ} \mathrm{C}$ for $18 \mathrm{~h}$, quenched with $\mathrm{H}_{2} \mathrm{O}$, and extracted with $\mathrm{CH}_{2} \mathrm{Cl}_{2}(3 \times 30 \mathrm{~mL})$, which was washed with brine, dried $\left(\mathrm{Na}_{2} \mathrm{SO}_{4}\right)$, and concentrated to give a pale yellow oil (102 $\left.\mathrm{mg}\right)$. Flash chromatography on silica gel (4:1 hexanes/EtOAc) gave $58 \mathrm{mg}$ of $(1 R, 7 \mathrm{a} S)$-tetrahydro-1-(2hydroxylheptyl)-1H,3H-pyrrolo[1,2-c]oxazol-3-one (13) (71\%) as a mixture of diastereomers.

To a stirred solution of $13(40 \mathrm{mg}, 0.17 \mathrm{mmol})$ in $\mathrm{CHCl}_{3}$ was added Dess-Martin periodinane $(70 \mathrm{mg}, 0.17 \mathrm{mmol})$. The reaction mixture was stirred at $25^{\circ} \mathrm{C}$ for $5 \mathrm{~min}$ and poured into a mixture of saturated aqueous $\mathrm{NaHCO}_{3}$ solution and saturated aqueous $\mathrm{Na}_{2} \mathrm{~S}_{2} \mathrm{O}_{3}$ solution $(2 \mathrm{~mL} / 2 \mathrm{~mL})$, to which ether $(10 \mathrm{~mL})$ was added. The resulting mixture was stirred at $25^{\circ} \mathrm{C}$ for $15 \mathrm{~min}$, diluted with ether $(80 \mathrm{~mL})$, washed with brine, dried $\left(\mathrm{Na}_{2} \mathrm{SO}_{4}\right)$, and concentrated to give 14 (38 mg, 99\%) as a pale yellow oil: ${ }^{1} \mathrm{H}$ NMR $5.05(\mathrm{ddd}, 1, J=8.5,7.3,6.1), 4.01$ (ddd, $1, J=$ $10.4,7.3,5.5), 3.63(\mathrm{ddd}, 1, J=11.6,8.6,8.0), 3.21(\mathrm{ddd}, 1, J=11.6,9.6,3.6), 3.09$ (dd, $1, J=$ 17.7, 6.1), $2.75(\mathrm{dd}, 1, J=17.7,8.5)$, [2.46 (apparent td, 2, $J=7.3,2.5)$ actually, $2.475(\mathrm{dt}, 1, J=$ $17,7.3)$ and $2.45(\mathrm{dt}, 1, J=17,7.3)], 2.03-2.11(\mathrm{~m}, 1), 1.82-1.95(\mathrm{~m}, 1), 1.62-1.69(\mathrm{~m}, 1), 1.59$ $(\mathrm{tt}, 2, J=7.3,7.3), 1.23-1.41(\mathrm{~m}, 5), 0.90(\mathrm{t}, 3, J=7.0) ;{ }^{13} \mathrm{C}$ NMR 207.4, 161.0, 71.7, 63.0, 45.7, 43.4, 43.2, 31.2, 25.2, 25.0, 23.2, 22.4, 13.8; IR 2956, 2930, 1710.

(3S,7aS)-Hexahydro-3-pentyl-1-pyrrolizinone (15). To a stirred solution of oxalyl chloride $(301 \mu \mathrm{L}, 3.45 \mathrm{mmol})$ in $\mathrm{CH}_{2} \mathrm{Cl}_{2}(15 \mathrm{~mL})$ was added DMSO $(490 \mu \mathrm{L}, 6.90 \mathrm{mmol})$ at $-78^{\circ} \mathrm{C}$. The resulting mixture was stirred at $-78^{\circ} \mathrm{C}$ for $10 \mathrm{~min}$ and a solution of $\mathbf{1 1}(136 \mathrm{mg}$, $0.69 \mathrm{mmol})$ in $\mathrm{CH}_{2} \mathrm{Cl}_{2}(3 \mathrm{~mL})$ was added and then $\mathrm{Et}_{3} \mathrm{~N}(2.4 \mathrm{~mL}, 17.26 \mathrm{mmol})$ was added. The reaction mixture was stirred at $-78{ }^{\circ} \mathrm{C}$ for $30 \mathrm{~min}$ and poured into $15 \mathrm{~mL}$ of saturated aqueous $\mathrm{NaHCO}_{3}$ solution. The organic layer was separated and the aqueous layer was extracted with ether $(3 \times 30 \mathrm{~mL})$. The combined organic layers were washed with brine, dried $\left(\mathrm{Na}_{2} \mathrm{SO}_{4}\right)$ and concentrated to give 15 as a unstable yellow oil (130 mg, 97\%), which was used immediately in 
the next step without further purification: ${ }^{1} \mathrm{H}$ NMR $3.57(\mathrm{dd}, 1, J=8.6,5.5), 3.06$ (ddd, $1, J=$ $11.6,6.7,6.7), 2.84-2.91(\mathrm{~m}, 2), 2.55(\mathrm{dd}, 1, J=17.7,6.7), 2.17(\mathrm{dd}, 1, J=17.7,8.6), 1.96-2.05$ $(\mathrm{m}, 1), 1.72-1.84(\mathrm{~m}, 3), 1.67-1.72(\mathrm{~m}, 1), 1.38-1.46(\mathrm{~m}, 1), 1.31(\mathrm{~m}, 6), 0.89(\mathrm{t}, 3, J=6.7)$; IR $2928,1750$.

(1S,3S,7aS)-Hexahydro-3-pentyl-1H-pyrrolizin-1-ol (16). To a stirred solution of 15 (130 mg, $0.67 \mathrm{mmol})$ in THF (3 mL) was added L-Selectride (1.0 M in THF, 3.3 mL, $3.3 \mathrm{mmol}$ ) dropwise at $-78^{\circ} \mathrm{C}$. The reaction mixture was stirred at $-78^{\circ} \mathrm{C}$ to $25^{\circ} \mathrm{C}$ for $4 \mathrm{~h}$ and quenched with $10 \%$ aqueous $\mathrm{NH}_{4} \mathrm{OH}$ solution. The organic layer was separated and the aqueous layer was extracted with $\mathrm{CH}_{2} \mathrm{Cl}_{2}(3 \times 30 \mathrm{~mL})$. The combined organic layers were washed with brine, dried $\left(\mathrm{Na}_{2} \mathrm{SO}_{4}\right)$ and concentrated to give a yellow oil. Flash chromatography on a column packed with a slurry of silica gel in a mixture of $1 \% \mathrm{Et}_{3} \mathrm{~N}$ in $\mathrm{CH}_{2} \mathrm{Cl}_{2}\left(\mathrm{CH}_{2} \mathrm{Cl}_{2}, 4: 1 \mathrm{CH}_{2} \mathrm{Cl}_{2} / \mathrm{MeOH}\right.$ then 100:1 $\mathrm{MeOH} /$ conc $\left.\mathrm{NH}_{4} \mathrm{OH}\right)$ gave $16(91 \mathrm{mg}, 69 \%)$ as a pale yellow oil: ${ }^{1} \mathrm{H}$ NMR 4.17 (br t, 1, J= 4.2), 3.72 (br, 1), 3.07 (ddd, 1, $J=9.8,4.9,4.9$ ), 2.85 (dddd, 1, $J=11.0,5.5,5.5,5.5$ ), 2.60 (ddd, $1, J=9.8,7.9,6.1), 2.08(\mathrm{dd}, 1, J=13.0,5.5), 1.85-1.96(\mathrm{~m}, 3), 1.70-1.77$ (m, 2), 1.56-1.66 (m, 1), 1.36-1.47 (m, 1), $1.30(\mathrm{~m}, 6), 0.89(\mathrm{t}, 3, J=6.7) ;{ }^{13} \mathrm{C} \mathrm{NMR} 71.9,69.9,65.1,54.9,43.9,32.1$ (2 C), 27.6, 27.0, 24.3, 22.6, 14.0; IR 3356, 2926, 1459; HRMS (DCI/ $\left.\mathrm{NH}_{3}\right)$ calcd for $\mathrm{C}_{12} \mathrm{H}_{24} \mathrm{NO}$ $\left(\mathrm{MH}^{+}\right)$198.1858, found 198.1861.

Fully protonated $16(\mathbf{1 6} \cdot \mathrm{HOAc})$ whose spectra match well with those of the ring portion of epohelmin B was obtained by adding 1 M HOAc (prepared from $58 \mu \mathrm{L}$ of HOAc in $1 \mathrm{~mL}$ of $\mathrm{CDCl}_{3}$ ) to the free amine 16 in $\mathrm{CDCl}_{3}$ in $1 \mu \mathrm{L}$ portions until the ${ }^{1} \mathrm{H}$ NMR spectrum didn't change anymore: $[\alpha]^{22}{ }_{\mathrm{D}}+48(c \mathrm{c} 0.16, \mathrm{MeOH}) ;{ }^{1} \mathrm{H}$ NMR 4.43 (ddd, $\left.1, J=8.6,4.3,4.3\right), 4.33$ (br t, $1, J=$ 4.3), 3.45 (ddd, $1, J=11.8,8.0,7.3), 3.25-3.33$ (m, 1), 2.87 (ddd, $1, J=11.0,5.5,5.5), 2.17-2.25$ (m, 2), 1.98 (s, 3, OAc), 1.91-2.14 (m, 4), 1.74-1.89 (m, 2), $1.32(\mathrm{~m}, 6), 0.88(\mathrm{t}, 3, J=6.7) ;{ }^{13} \mathrm{C}$ NMR 177 (br, OAc), 70.9, 69.9, 66.9, 52.7, 42.3, 31.5, 30.8, 26.7 (2 C), 24.2, 23 (br, OAc), 22.4, 13.9.

(1R)-1-[(S)- $N$-Benzyloxycarbonylpyrrolidin-2-yl]-1-hydroxyl-7-(4-methyl-2,6,7trioxabicyclo[2.2.2]oct-1-yl)-heptan-3-one (18). Lithium diisopropylamide was prepared from 
diisopropylamine (1.52 mL, $10.86 \mathrm{mmol})$ and $n$-BuLi (1.6 M in hexanes, $6.8 \mathrm{~mL}, 10.86 \mathrm{mmol})$ in THF $(100 \mathrm{~mL})$ at $0{ }^{\circ} \mathrm{C}$. This solution was cooled to $-78{ }^{\circ} \mathrm{C}$ and treated with 5-(4-methyl2,6,7-trioxabicyclo[2.2.2] oct-1-yl)-2-pentanone $(\mathbf{1 7})^{16}(1.81 \mathrm{~g}, 9.05 \mathrm{mmol})$ in $20 \mathrm{~mL}$ of dry THF by a syringe pump over $1 \mathrm{~h}$. The reaction mixture was stirred for another $30 \mathrm{~min}$ at $-78{ }^{\circ} \mathrm{C}$ and treated with a solution of benzyl (2S)-2-formyl-1-pyrrolidinecarboxylate (9) ${ }^{7}(2.10 \mathrm{~g}, 9.05 \mathrm{mmol})$ in THF $(10 \mathrm{~mL})$ via a syringe pump over $30 \mathrm{~min}$. The mixture was stirred at $-78{ }^{\circ} \mathrm{C}$ for $2 \mathrm{~h}$ and quenched with acetic acid $(1.56 \mathrm{~mL}, 27.15 \mathrm{mmol})$ in ether $(20 \mathrm{~mL})$. The resulting mixture was diluted with cold EtOAc $(450 \mathrm{~mL})$, washed with cold saturated aqueous $\mathrm{NaHCO}_{3}$ solution and brine, dried $\left(\mathrm{MgSO}_{4}\right)$, and concentrated to give 18 (4.44 g) as a yellow foam. Crude 18 was used in the next step without further purification. Analytically pure $\mathbf{1 8}$ can be obtained by flash chromatography on silica gel (packed with a slurry of silica gel in a mixture of $1 \% \mathrm{Et}_{3} \mathrm{~N}$ in hexanes, 2:1 hexanes/EtOAc): $[\alpha]^{22}{ }_{\mathrm{D}}-41$ (c 1.04, MeOH); ${ }^{1} \mathrm{H}$ NMR 7.31-7.38 (m, 5), 5.08-5.24 $(\mathrm{m}, 2), 4.06-4.19(\mathrm{~m}, 1), 3.80-3.98(\mathrm{~m}, 1), 3.88(\mathrm{~s}, 6), 3.51-3.60(\mathrm{~m}, 1), 3.32-3.37(\mathrm{~m}, 1), 2.10-$ $2.58(\mathrm{~m}, 4), 1.64-1.96(\mathrm{~m}, 8), 0.79$ (s, 3); IR 3453, 2958, 2878, 1699, 1415; HRMS (DCI/NH3) calcd for $\mathrm{C}_{24} \mathrm{H}_{34} \mathrm{NO}_{7}\left(\mathrm{MH}^{+}\right)$448.2335, found 448.2349.

\section{Methyl (7R)-7-[(S)- $N$-Benzyloxycarbonylpyrrolidin-2-yl]-7-hydroxyl-5-oxo-}

heptanoate (19). Crude 18 (4.44 g) was dissolved in a mixture of $\mathrm{HOAc} / \mathrm{THF} / \mathrm{H}_{2} \mathrm{O}(120 \mathrm{~mL} / 60$ $\mathrm{mL} / 30 \mathrm{~mL}$ ) and the resulting mixture was stirred at $25^{\circ} \mathrm{C}$ for $3 \mathrm{~h}$ and concentrated to give a yellow oil (5.2 g). This crude yellow oil was dissolved in $\mathrm{MeOH}(150 \mathrm{~mL})$ and $\mathrm{K}_{2} \mathrm{CO}_{3}(2.5 \mathrm{~g}$, $18.11 \mathrm{mmol}$ ) was added. The reaction mixture was stirred at $25^{\circ} \mathrm{C}$ for $2 \mathrm{~h}$ and quenched with $\mathrm{H}_{2} \mathrm{O}$. The resulting mixture was extracted with $\mathrm{CH}_{2} \mathrm{Cl}_{2}(3 \times 120 \mathrm{~mL})$ and the combined organic layers were washed with brine, dried $\left(\mathrm{MgSO}_{4}\right)$, and concentrated to give a yellow oil, which was purified by flash chromatography on silica gel (1:1 hexanes/EtOAc) to give 19 (2.56 g, 75\% yield from 17) as a colorless oil: $[\alpha]^{22}{ }_{\mathrm{D}}-51$ (c 1.30, MeOH); ${ }^{1} \mathrm{H}$ NMR 7.30-7.38 (m, 5), 5.10$5.25(\mathrm{~m}, 2), 4.09-4.18(\mathrm{~m}, 1), 3.80-4.12(\mathrm{~m}, 1), 3.67(\mathrm{~s}, 3), 3.52-3.58(\mathrm{~m}, 1), 3.31-3.37(\mathrm{~m}, 1)$, 2.32-2.59 (m, 6), 1.80-1.98 (m, 6); IR 3448, 2953, 1735, 1701, 1416; HRMS (DCI/NH $)$ calcd for $\mathrm{C}_{20} \mathrm{H}_{28} \mathrm{NO}_{6}\left(\mathrm{MH}^{+}\right)$378.1917, found 378.1915. 


\section{Methyl (7R)-7-[(S)-N-Benzyloxycarbonylpyrrolidin-2-yl]-7-(1-ethoxyethoxy)-5-oxo-}

heptanoate (20). To a solution of 19 (2.56 g, $6.79 \mathrm{mmol})$ in $\mathrm{CH}_{2} \mathrm{Cl}_{2}(100 \mathrm{~mL})$ under $\mathrm{N}_{2}$ was added ethyl vinyl ether $(13 \mathrm{~mL}, 135.81 \mathrm{mmol})$ and PPTS (171 $\mathrm{mg}, 0.68 \mathrm{mmol})$. The reaction mixture was stirred at $25^{\circ} \mathrm{C}$ for $1.5 \mathrm{~h}$ and diluted with ether $(350 \mathrm{~mL})$, which was washed with $\mathrm{H}_{2} \mathrm{O}$ and brine, dried $\left(\mathrm{Na}_{2} \mathrm{SO}_{4}\right)$, and concentrated to give 20 (2.97 g, 97 \%) as a pale yellow oil, which was used without further purification: $[\alpha]^{22}{ }_{\mathrm{D}}-42\left(\right.$ c 1.20, MeOH); ${ }^{1} \mathrm{H}$ NMR 7.31-7.44 (m, 5), 5.07-5.30 (m, 2), 4.42-4.72 (m, 2), 3.74-3.83 (m, 1), $3.66(\mathrm{~s}, 3), 3.39-3.62(\mathrm{~m}, 2), 3.24-3.38$ $(\mathrm{m}, 2), 2.25-2.74(\mathrm{~m}, 5), 1.77-2.10(\mathrm{~m}, 7), 1.17-1.29(\mathrm{~m}, 3), 1.12(\mathrm{t}, 3, J=7.0)$; IR 2978, 1738, 1702, 1414; HRMS (DCM/NBA/NaCl) calcd for $\mathrm{C}_{24} \mathrm{H}_{35} \mathrm{NO}_{7} \mathrm{Na}\left(\mathrm{MNa}^{+}\right) 472.2311$, found 472.2313 .

Methyl (1R,3S,7aS)-1-(1-Ethoxyethoxy)-hexahydro-1H-pyrrolizine-3-butyrate (21). A mixture of $20(620 \mathrm{mg}, 1.38 \mathrm{mmol})$ and $\mathrm{Pd}(\mathrm{OH})_{2}(20 \mathrm{wt} \% \mathrm{Pd}$ on carbon, $97 \mathrm{mg})$ in $\mathrm{MeOH}$ $(100 \mathrm{~mL})$ was degassed, stirred under $\mathrm{H}_{2}$ for $12 \mathrm{~h}$ and filtered through Celite, which was washed with $\mathrm{MeOH}$. The filtrate was concentrated to give 21 (382 mg, 93\%) as a yellow oil. Crude 21 was used in next step without further purification. An analytical pure sample can be obtained by flash chromatography on silica gel $\left(10: 1 \mathrm{CH}_{2} \mathrm{Cl}_{2} / \mathrm{MeOH}\right):[\alpha]^{22}{ }_{\mathrm{D}}-3(c 0.53, \mathrm{MeOH}) ;{ }^{1} \mathrm{H} \mathrm{NMR}$ $4.74(\mathrm{q}, 1, J=4.5), 3.83(\mathrm{ddd}, 1, J=9.7,6.1,6.1), 3.667(\mathrm{~s}, 0.5 \times 3), 3.664(\mathrm{~s}, 0.5 \times 3), 3.59-3.65$ (m, 1), 3.44-3.55 (m, 2), 3.03 (ddd, 1, J=10.4, 6.7, 6.7), 2.58-2.68 (m, 2), 2.26-2.39 (m, 3), 1.92-2.00 (m, 1), 1.49-1.82 (m, 8), $1.31(\mathrm{~d}, 3, J=4.5), 1.20(\mathrm{t}, 3, J=7.0) ;{ }^{13} \mathrm{C}$ NMR 173.8, (99.0, 98.5), (79.29, 79.26), (69.7, 69.6), (64.85, 64.83), (60.2, 59.7), (54.44, 54.37), 51.4, (40.1, 39.1), 35.7, (34.00, 33.99), (30.6, 30.4), (25.4, 25.2), 22.3, (20.3, 20.2), (15.2, 15.1); IR 2933, 1739; HRMS (DCI/NH$)$ calcd for $\mathrm{C}_{16} \mathrm{H}_{30} \mathrm{NO}_{4}\left(\mathrm{MH}^{+}\right)$300.2175, found 300.2180.

Dimethyl (1R,3S,7aS)-1-(1-Ethoxyethoxy)-hexahydro-1H-pyrrolizine-3-(2-oxopentanephosphonate) (22). To a stirred solution of dimethyl methylphosphonate (1.53 mL, $14.1 \mathrm{mmol})$ in dry THF $(60 \mathrm{~mL})$ at $-78^{\circ} \mathrm{C}$ was added $n$-BuLi $(1.6 \mathrm{M}$ in hexanes, $8.8 \mathrm{~mL}, 14.1$ mmol). The resulting mixture was stirred at $-78^{\circ} \mathrm{C}$ for $1 \mathrm{~h}$ and 21 (422 $\left.\mathrm{mg}, 1.41 \mathrm{mmol}\right)$ in dry THF $(20 \mathrm{~mL})$ was added dropwise. The reaction mixture was stirred at $-78^{\circ} \mathrm{C}$ to $25^{\circ} \mathrm{C}$ for $12 \mathrm{~h}$, 
quenched with saturated aqueous $\mathrm{NH}_{4} \mathrm{Cl}$ solution, diluted with EtOAc $(250 \mathrm{~mL})$, washed with brine, dried $\left(\mathrm{Na}_{2} \mathrm{SO}_{4}\right)$, and concentrated to give a pale yellow oil. Flash chromatography on silica gel (10:1 $\left.\mathrm{CH}_{2} \mathrm{Cl}_{2} / \mathrm{MeOH}\right)$ gave $22(447 \mathrm{mg}, 81 \%)$ as a yellow oil: $[\alpha]^{22}{ }_{\mathrm{D}}+2(c 0.32$, $\mathrm{MeOH}) ;{ }^{1} \mathrm{H}$ NMR 4.73 (q, 1, $\left.J=5.0\right), 3.79$ (d, 6, $\left.J=11.0\right), 3.75-3.85(\mathrm{~m}, 1), 3.59-3.68(\mathrm{~m}, 1)$, 3.42-3.51 (m, 2), 3.09 (d, 2, $J=23.2), 2.99(\mathrm{ddd}, 1, J=11.0,6.7,6.1), 2.57-2.67(\mathrm{~m}, 4), 2.29$ (ddd, $1, J=11.6,9.8,6.1), 1.95(\mathrm{dddd}, 1, J=12.2,7.3,6.7,5.5), 1.74-1.81(\mathrm{~m}, 2), 1.55-1.70$ (m, 5), 1.40-1.50 (m, 1), 1.31 (d, 3, $J=5.0), 1.20$ (t, 3, $J=7.0) ;{ }^{13} \mathrm{C}$ NMR $201.6(\mathrm{~d}, 1, J=6.9),(99.0$, 98.6), (79.44, 79.38), (69.72, 69.68), 64.9, (60.2, 59.7), (54.6, 54.5), 52.9 (d, 2 C, J = 6.9), 44.1, 41.2 (d, 1, J = 127.4), (40.2, 39.2), 35.8 (br s), (30.6, 30.4), (25.5, 25.2), 20.7, (20.3, 20.2), (15.2, 15.1); IR 2938, 1704, 1236, 1054; HRMS (DCI/NH$)$ calcd for $\mathrm{C}_{18} \mathrm{H}_{35} \mathrm{NO}_{6} \mathrm{P}\left(\mathrm{MH}^{+}\right)$392.2202, found 392.2214 .

\section{1-[(1R,3S,7aS)-1-(1-Ethoxyethoxy)-hexahydro-1H-pyrrolizin-3-yl]-5-undecen-4-one}

(23). To a stirred mixture of hexanes-washed $\mathrm{NaH}$ (60\% dispersion in mineral oil, $16 \mathrm{mg}, 0.40$ mmol) in dry $\mathrm{THF}(4 \mathrm{~mL})$ at $0{ }^{\circ} \mathrm{C}$ under $\mathrm{N}_{2}$ was added a solution of $22(142 \mathrm{mg}, 0.36 \mathrm{mmol})$ in dry THF $(4 \mathrm{~mL})$ dropwise. The cooling bath was removed and the reaction mixture was stirred at $25^{\circ} \mathrm{C}$ for $1 \mathrm{~h}$ and cooled to $0{ }^{\circ} \mathrm{C}$. A solution of $n$-hexanal $(48 \mu \mathrm{L}, 0.40 \mathrm{mmol})$ in dry THF (4 $\mathrm{mL}$ ) was added and the resulting mixture was stirred from $0{ }^{\circ} \mathrm{C}$ to $25^{\circ} \mathrm{C}$ for $3 \mathrm{~h}$. Saturated aqueous $\mathrm{NH}_{4} \mathrm{Cl}$ solution was added to quench the reaction. The resulting mixture was diluted with EtOAc $(120 \mathrm{~mL})$, washed with brine, dried $\left(\mathrm{Na}_{2} \mathrm{SO}_{4}\right)$, and concentrated to give pure 23 (126 mg, 95\%) as a pale yellow oil: $[\alpha]^{22}{ }_{\mathrm{D}}-2$ (c 1.56, MeOH); ${ }^{1} \mathrm{H}$ NMR $6.83(\mathrm{dt}, 1, J=15.8,7.3)$, 6.08 (br d, 1, $J=15.8), 4.72-4.77$ (m, 1), 3.87 (ddd, 1, $J=9.7,6.7,6.1$ ), 3.58-3.67 (m, 2), 3.42$3.52(\mathrm{~m}, 1), 3.12-3.18(\mathrm{~m}, 1), 2.65-2.74(\mathrm{~m}, 2), 2.56-2.61(\mathrm{~m}, 2), 2.30-2.36(\mathrm{~m}, 1), 2.21(\mathrm{dt}, 2, J=$ 7.3, 6.7), 1.97-2.05 (m, 1), 1.59-1.87 (m, 8), 1.43-1.50 (m, 2), 1.31 (d, 3, J= 5.5), 1.28-1.33 (m, 4), $1.20(\mathrm{t}, 3, J=7.3), 0.90(\mathrm{t}, 3, J=7.0) ;{ }^{13} \mathrm{C}$ NMR 200.4, 147.7, 130.3, (99.0, 98.6), 79.2 (br s), (69.78, 69.75), 65.3, (60.3, 59.8), (54.5, 54.4), (40.1, 39.1), 39.9, 32.4, 31.3, (30.6, 30.4), 27.72, 27.66, (25.4, 25.2), 22.4, 21.6, (20.32, 20.26), (15.24, 15.19), 13.9; IR 2931, 1672, 1629, 1135; HRMS (DCI/NH$)$ calcd for $\mathrm{C}_{22} \mathrm{H}_{40} \mathrm{NO}_{3}\left(\mathrm{MH}^{+}\right)$366.3008, found 366.3019. 


\section{1-[(1R,3S,7aS)-Hexahydro-1-hydroxy-1H-pyrrolizin-3-yl]-5-undecen-4-one}

(Epohelmin A, 24). A mixture of 23 (200 mg, $0.55 \mathrm{mmol})$ in 10\% aqueous HOAc solution (50 $\mathrm{mL}$ ) was stirred at $25^{\circ} \mathrm{C}$ for $4 \mathrm{~h}$ and concentrated to give $24 \cdot \mathrm{HOAc}(193 \mathrm{mg}, 100 \%$ ) as a yellow oil: ${ }^{1} \mathrm{H}$ NMR 6.84 (dt, 1, $\left.J=15.8,7.3\right), 6.07$ (br d, 1, $\left.J=15.8\right), 4.15-4.19$ (m, 2), 3.48 (ddd, 1, $J$ $=12.2,8.0,7.3), 2.96-3.03(\mathrm{~m}, 2), 2.61(\mathrm{t}, 2, J=7.3), 2.53-2.58(\mathrm{~m}, 1), 2.22-2.27(\mathrm{~m}, 1), 2.21$ $(\mathrm{dt}, 2, J=7.3,7.3), 2.01-2.08(\mathrm{~m}, 3), 2.02(\mathrm{~s}, 3, \mathrm{OAc}), 1.91-1.97(\mathrm{~m}, 1), 1.74-1.89(\mathrm{~m}, 2), 1.64$ $(\mathrm{tt}, 2, J=7.3,7.3), 1.47(\mathrm{tt}, 2, J=7.3,7.3), 1.29-1.34(\mathrm{~m}, 4), 0.90(\mathrm{t}, 3, J=7.0) ;{ }^{13} \mathrm{C}$ NMR 199.6, 177 (br, OAc), 148.2, 130.1, 74.2, 73.6, 67.3, 52.3, 40.5, 39.0, 32.4, 31.3, 31.1, 28.4, 27.7, 24.2, 23 (br, OAc), 22.4, 21.0, 13.9.

A solution of epohelmin acetate $(\mathbf{2 4} \cdot \mathrm{HOAc})$ in EtOAc was washed with saturated aqueous $\mathrm{NaHCO}_{3}$ solution, dried $\left(\mathrm{Na}_{2} \mathrm{SO}_{4}\right)$, and concentrated to give pure 24 as a yellow oil: ${ }^{1} \mathrm{H}$ NMR 6.83 (dt, 1, $J=15.8,7.3$ ), 6.08 (br d, 1, $J=15.8$ ), 3.90 (ddd, 1, $J=9.2,6.7,6.1$ ), 3.36 (ddd, $1, J=6.7,6.1,5.5), 2.95(\mathrm{ddd}, 1, J=11.0,7.3,6.7), 2.59-2.66(\mathrm{~m}, 2), 2.55-2.58(\mathrm{~m}, 2), 2.33$ (ddd, $1, J=12.2,6.1,6.1), 2.21(\mathrm{dt}, 2, J=7.3,6.7), 1.94(\mathrm{dddd}, 1, J=14.1,7.3,7.0,6.7), 1.72-$ $1.79(\mathrm{~m}, 2), 1.56-1.68(\mathrm{~m}, 6), 1.43-1.50(\mathrm{~m}, 2), 1.29-1.34(\mathrm{~m}, 4), 0.90(\mathrm{t}, 3, J=7.0) ;{ }^{13} \mathrm{C} \mathrm{NMR}$ $200.5,147.6,130.3,76.8,72.2,65.1,54.5,41.9,40.0,36.6,32.4,31.3,30.0,27.7,25.0,22.4$, 21.7, 13.9; IR 3332, 2956, 2930, 2863, 1670, 1628, 1457, 1373, 1105; HRMS (DCI/NH $\mathrm{NH}_{3}$ calcd for $\mathrm{C}_{18} \mathrm{H}_{32} \mathrm{NO}_{2}\left(\mathrm{MH}^{+}\right)$294.2433, found 294.2430.

$1 \mathrm{M} \mathrm{HOAc}$ in $\mathrm{CDCl}_{3}$ was added to the free amine 24 in $\mathrm{CDCl}_{3}$ in $1 \mu \mathrm{L}$ portions until the spectrum didn't change anymore to give $24 \cdot H O A c$. The spectral data for 24 that is $85-90 \%$ protonated with HOAc are identical to those reported for epohelmin A: $[\alpha]^{22}{ }_{\mathrm{D}}+22(c 0.14$, $\mathrm{MeOH}) ;\left\{\right.$ lit. ${ }^{1}[\alpha]^{22}{ }_{\mathrm{D}}+22($ c 0.14, $\left.\mathrm{MeOH})\right\} ;{ }^{1} \mathrm{H}$ NMR 6.84 (dt, $\left.1, J=15.8,7.0\right), 6.07$ (br d, $1, J=$ 15.8), $4.19(\mathrm{ddd}, 1, J=6.7,6.1,3.1), 4.11(\mathrm{ddd}, 1, J=8.0,8.0,3.1), 3.43(\mathrm{ddd}, 1, J=12.2,8.0$, 8.0), 2.96-3.04 (m, 2), 2.59-2.63 (m, 3), 2.25-2.30 (m, 1), 2.22 (br dt, 2, J = 7.0, 7.0), 2.01-2.08 (m, 3), 2.01 (s, 3, OAc), 1.90-1.97 (m, 1), 1.80-1.86 (m, 1), 1.70-1.77 (m, 1), 1.64 (tt, 2, J= 7.3, 7.3), $1.47(\mathrm{tt}, 2, J=7.3,7.3), 1.30-1.34(\mathrm{~m}, 4), 0.90(\mathrm{t}, 3, J=7.0) ;{ }^{13} \mathrm{C} \mathrm{NMR} 199.6,177$ (br, 
OAc), 148.2, 130.1, 74.1, 73.7, 67.3, 52.1, 40.6, 39.1, 32.4, 31.3, 31.2, 28.4, 27.7, 24.2, 23 (br, OAc), 22.4, 21.1, 13.9 .

1-[(3S,7aS)-Hexahydro-1-oxo-1H-pyrrolizin-3-yl]-5-undecen-4-one . To a stirred solution of oxalyl chloride $(265 \mu \mathrm{L}, 3.04 \mathrm{mmol})$ in $\mathrm{CH}_{2} \mathrm{Cl}_{2}(10 \mathrm{~mL})$ was added DMSO $(431 \mu \mathrm{L}$, $6.08 \mathrm{mmol}$ ) at $-78^{\circ} \mathrm{C}$. The resulting mixture was stirred at $-78{ }^{\circ} \mathrm{C}$ for $10 \mathrm{~min}$ and a solution of 24 (89 mg, $0.30 \mathrm{mmol})$ in $\mathrm{CH}_{2} \mathrm{Cl}_{2}(3 \mathrm{~mL})$ was added followed by $\mathrm{Et}_{3} \mathrm{~N}$ (1.7 mL, $\left.12.20 \mathrm{mmol}\right)$. The reaction mixture was stirred at $-78^{\circ} \mathrm{C}$ for $1 \mathrm{~h}$ and poured into $15 \mathrm{~mL}$ of $\mathrm{H}_{2} \mathrm{O}$. The organic layer was separated and the aqueous layer was extracted with ether $(3 \times 30 \mathrm{~mL})$. The combined organic layers were washed with $\mathrm{H}_{2} \mathrm{O}$ and brine, dried $\left(\mathrm{Na}_{2} \mathrm{SO}_{4}\right)$, and concentrated to give crude dione (86 mg, 97\%) as an unstable yellow oil, which was used immediately in the next step without further purification: ${ }^{1} \mathrm{H}$ NMR $6.84(\mathrm{dt}, 1, J=15.8,6.7), 6.08(\mathrm{dd}, 1, J=15.8,1.2), 3.55$ $(\mathrm{dd}, 1, J=8.5,5.5), 3.05(\mathrm{ddd}, 1, J=15.3,6.7,6.7), 2.89-2.92(\mathrm{~m}, 1), 2.85(\mathrm{ddd}, 1, J=15.3,6.1$, $6.1), 2.59(\mathrm{t}, 2, J=7.3), 2.56(\mathrm{dd}, 1, J=17.7,6.7), 2.21(\mathrm{tdd}, 2, J=7.3,6.7,1.2), 2.18(\mathrm{dd}, 1, J=$ $17.7,8.5), 1.98-2.05(\mathrm{~m}, 1), 1.75-1.84(\mathrm{~m}, 4), 1.60-1.73(\mathrm{~m}, 2), 1.41-1.51(\mathrm{~m}, 3), 1.29-1.35(\mathrm{~m}$ 4), $0.90(\mathrm{t}, 3, J=7.0)$; IR 2930, 2872, 1749, 1671.

(1S,3S,7aS)-Hexahydro-3-(4-hydroxyl-5-undecenyl)-1H-pyrrolizin-1-ol (25). To a stirred solution of the above crude dione $(86 \mathrm{mg}, 0.29 \mathrm{mmol})$ in THF $(3 \mathrm{~mL})$ was added LSelectride $(1.0 \mathrm{M}$ in THF, $2.9 \mathrm{~mL}, 2.9 \mathrm{mmol})$ dropwise at $-78^{\circ} \mathrm{C}$. The reaction mixture was stirred at $-78^{\circ} \mathrm{C}$ for $1 \mathrm{~h}$, warmed to $25^{\circ} \mathrm{C}$, and stirred for another $3 \mathrm{~h}$. The resulting mixture was then quenched with $10 \% \mathrm{NH}_{4} \mathrm{OH}$. The organic layer was separated and the aqueous layer was extracted with $\mathrm{CH}_{2} \mathrm{Cl}_{2}(3 \times 30 \mathrm{~mL})$. The combined organic layers were washed with brine, dried $\left(\mathrm{Na}_{2} \mathrm{SO}_{4}\right)$, and concentrated to give a yellow oil. Flash chromatography on silica gel (1:1 $\left.\mathrm{CH}_{2} \mathrm{Cl}_{2} / \mathrm{MeOH}\right)$ gave $25(74 \mathrm{mg}, 85 \%)$ as a pale yellow oil that is a mixture of diastereomers: $[\alpha]^{22}{ }_{\mathrm{D}}+20(c \mathrm{0.55}, \mathrm{MeOH}) ;{ }^{1} \mathrm{H} \mathrm{NMR}\left(\mathrm{CD}_{3} \mathrm{OD}\right) 5.63(\mathrm{dt}, 1, J=15.2,6.7), 5.42$ (ddt, $1, J=15.2$, 7.0, 1.2), 4.14 (br dd, $1, J=3.7,3.7$ ), 3.98 (dt, 1, $J=7.0,6.7$ ), 3.67 (ddd, 1, $J=8.5,4.9,3.7$ ), 2.94-3.05 (m, 2), 2.70-2.76 (m ,1), 1.93-2.16 (m, 6), 1.78-1.89 (m, 1), 1.64-1.74 (m, 3), 1.29-1.58 (m, 10), 0.91 (t, 3, $J=7.0) ;{ }^{13} \mathrm{C}$ NMR (CD $\left.{ }_{3} \mathrm{OD}\right)(134.5,134.4),(132.8,132.7), 73.6,(72.0,71.9)$, 
67.0, (55.69, 55.66), (44.34, 44.29), 38.7, 36.4, 33.4, 32.7, 30.3, 28.3, 25.4, 24.6, 24.5, 23.7, 14.6; IR 3346, 2927, 2858, 1458; HRMS (DCI/NH $\mathrm{NH}_{3}$ calcd for $\mathrm{C}_{18} \mathrm{H}_{34} \mathrm{NO}_{2}\left(\mathrm{MH}^{+}\right)$296.2590, found 296.2591 .

\section{1-[(1S,3S,7aS)-Hexahydro-1-hydroxyl-1H-pyrrolizin-3-yl]-5-undecen-4-one}

(Epohelmin B, 26). To a stirred solution of 25 (47 mg, $0.16 \mathrm{mmol})$ in $\mathrm{CHCl}_{3}(5 \mathrm{~mL})$ was added Dess-Martin periodinane $(104 \mathrm{mg}, 0.24 \mathrm{mmol})$ in one portion. The resulting mixture was stirred at $25{ }^{\circ} \mathrm{C}$ for $1 \mathrm{~h}$ and poured into a mixture of saturated aqueous $\mathrm{Na}_{2} \mathrm{~S}_{2} \mathrm{O}_{3}$ solution and saturated aqueous $\mathrm{NaHCO}_{3}$ solution $(5 \mathrm{~mL} / 5 \mathrm{~mL})$, to which $15 \mathrm{~mL}$ of ether was added. The resulting mixture was stirred at $25^{\circ} \mathrm{C}$ for $30 \mathrm{~min}$. The organic layer was separated and the aqueous layer was extracted with EtOAc $(3 \times 30 \mathrm{~mL})$. The combined organic layers were washed with saturated aqueous $\mathrm{NaHCO}_{3}$ and brine, dried $\left(\mathrm{Na}_{2} \mathrm{SO}_{4}\right)$, and concentrated to give pure 26 (45 mg, 98\%) as a yellow oil: ${ }^{1} \mathrm{H}$ NMR 6.83 (dt, 1, $\left.J=15.9,7.3\right), 6.08$ (br d, 1, J=15.9), 4.15 (br, 1), $3.64(\mathrm{ddd}, 1, J=7.0,3.7,3.7), 3.03(\mathrm{ddd}, 1, J=8.4,4.2,4.2), 2.86(\mathrm{dddd}, 1, J=11.6,6.1,5.5$, 5.5), 2.52-2.58 (m, 3), 2.20 (dt, 2, $J=7.3,6.7), 2.09$ (dd, 1, $J=11.0,5.5), 1.86-1.91(\mathrm{~m}, 3), 1.66-$ $1.74(\mathrm{~m}, 2), 1.54-1.66(\mathrm{~m}, 3), 1.40-1.48(\mathrm{~m}, 3), 1.30(\mathrm{~m}, 4), 0.89(\mathrm{t}, 3, J=7.0) ;{ }^{13} \mathrm{C}$ NMR 200.6, $147.6,130.3,72.0,69.8,64.7,55.1,43.9,40.1,36.4,32.4,31.3,27.75,27.66,24.3,22.4,21.9$, 13.9; IR 3392, 2956, 2928, 2859, 1666, 1628, 1459; HRMS (DCI/NH $\mathrm{NH}_{3}$ calcd for $\mathrm{C}_{18} \mathrm{H}_{32} \mathrm{NO}_{2}$ $\left(\mathrm{MH}^{+}\right)$294.2433, found 294.2436.

Epohelmin B acetate (26•HOAc) whose spectral data are identical with those reported for epohelmin B was obtained by titration of 26 with $1 \mathrm{M} \mathrm{HOAc}$ in $\mathrm{CDCl}_{3}$ until the spectrum didn't change any more: $[\alpha]^{22}{ }_{\mathrm{D}}+29\left(c\right.$ 0.28, MeOH); $\left\{\right.$ lit. $\left.^{1}[\alpha]^{22}{ }_{\mathrm{D}}+25(c 0.28, \mathrm{MeOH})\right\} ;{ }^{1} \mathrm{H}$ NMR 6.85 (dt, $1, J=16.0,7.0), 6.07$ (br d, 1, $J=16.0$ ), 4.46 (ddd, 1, $J=8.5,4.3,4.3$ ), 4.37 (br, 1), 3.50 (ddd, $1, J=11.5,8.0,7.3), 3.28-3.37(\mathrm{~m}, 1), 2.90(\mathrm{ddd}, 1, J=11.4,6.1,5.5), 2.62(\mathrm{t}, 2, J=7.0)$, 2.18-2.24 (m, 4), 2.00-2.10 (m, 3), 2.00 (s, 3, OAc), 1.78-2.00 (m, 3), 1.66 (tt, 2, J= 7.3, 6.7), 1.47 (tt, 2, $J=7.3,6.7), 1.29-1.35$ (m, 4), 0.90 (t, 3, $J=7.0) ;{ }^{13} \mathrm{C}$ NMR 199.8, 176.7 (OAc), 148.2, 130.1, 71.1, 69.9, 66.8, 52.9, 42.2, 39.2, 32.4, 31.3, 30.3, 27.7, 26.7, 24.1, 22.5 (OAc), $22.4,21.2,13.9$. 

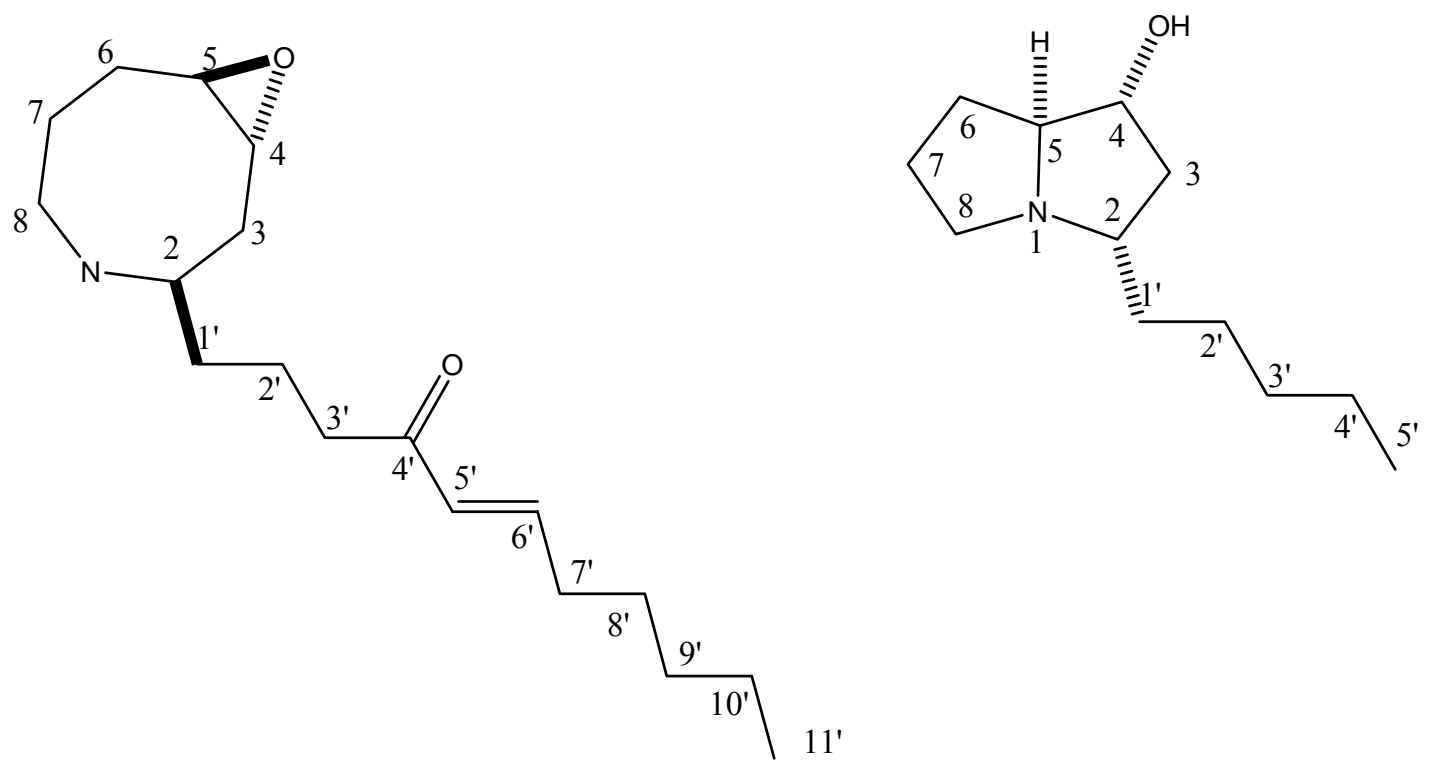

Comparison of the spectral data of the proposed structure of epohelmin A (1) and Model 11. Both compounds are $85-90 \%$ converted to the acetate salt. The numbering system is taken from reference 1 and differs from that used in the experimental section for pyrrolizidines.

\section{Proposed Structure of Epohelmins A (1) position ${ }^{13} \mathrm{C} \quad{ }^{1} \mathrm{H}$}

$2 \quad 67.3 \quad 2.99(1, \mathrm{~m})$

$3 \quad 40.9 \quad 2.06(2, \mathrm{~m})^{\mathrm{a}}$

$4 \quad 74.3 \quad 4.17(1, \mathrm{td}, 6.3,3.0)$

$5 \quad 73.9 \quad 4.11(1, \mathrm{td}, 8.3,3.3)$

$6 \quad 28.4 \quad 2.26(1, \mathrm{~m})$

$$
1.72(1, \mathrm{~m})
$$

$7 \quad 24.2 \quad 2.04(2, \mathrm{~m})$

$8 \quad 51.9 \quad 3.43(1, \mathrm{dt}, 12.0,8.0)$

$2.96(1, \mathrm{dt}, 12.0,6.0)$

1 ' $\quad 31.2 \quad 1.92(1, \mathrm{~m})$

$1.82(1, \mathrm{~m})$

2' $\quad 21.1 \quad 1.64(2, \mathrm{ddt}, 7.7,7.7,7.7)$

3' $\quad 39.1 \quad 2.60(2, \mathrm{t}, 7.0)$

4' $\quad 199.6$

5, $\quad 130.1 \quad 6.07(1, \mathrm{dt}, 16.0,1.5)$

6' $148.2 \quad 6.83(1, \mathrm{dt}, 15.7,6.9)$

7 , $\quad 32.5 \quad 2.21(2, \mathrm{ddt}, 7.0,7.0,1.5)$

$8, \quad 27.7 \quad 1.47(2, \mathrm{tt}, 7.4,7.4)$

$9^{\prime} \quad 31.3 \quad 1.31(2, \mathrm{~m})$

$10, \quad 22.4 \quad 1.29(2, \mathrm{~m})$

$11, \quad 13.9 \quad 0.90(3, \mathrm{t}, 7.0)$

a) Careful examination of the ${ }^{1} \mathrm{H}$ NMR spectrum of epohelmin $\mathrm{A}$ indicates that one of these hydrogens absorbs at $\delta 2.60$ as in model $\mathbf{1 1}$

\section{Model Compound 11 position ${ }^{13} \mathrm{C}{ }^{1} \mathrm{H}$}

$\begin{array}{lll}2 & 67.3 & 2.95(1, \mathrm{~m}) \\ 3 & 41.0 & 2.06(1, \mathrm{~m}) \\ & & 2.58(1, \mathrm{ddd}, 13.4,6.7,6.7) \\ 4 & 74.1 & 4.18(1, \mathrm{br} \mathrm{t}, 6) \\ 5 & 73.8 & 4.11(1, \mathrm{br} \mathrm{t}, 8) \\ 6 & 28.4 & 2.26(1, \mathrm{dddd}, 12.7,6.1,6.1,6.1) \\ & & 1.73(1, \mathrm{dddd}, 12.7,7,7,7) \\ 7 & 24.1 & 2.05(2, \mathrm{~m}) \\ 8 & 51.7 & 3.45(1, \mathrm{ddd}, 12.2,8.0,8.0) \\ & & 2.96(1, \mathrm{ddd}, 12.2,6,6) \\ 1 & 31.4 & 1.90(1, \mathrm{~m}) \\ & & 1.82(1, \mathrm{~m}) \\ 2 & 26.6 & 1.30(2, \mathrm{~m}) \\ 3 & 31.5 & 1.30(2, \mathrm{~m}) \\ 4 & 22.4 & 1.30(2, \mathrm{~m}) \\ 5 & 13.9 & 0.89(3, \mathrm{t}, 6.1)\end{array}$

(1)




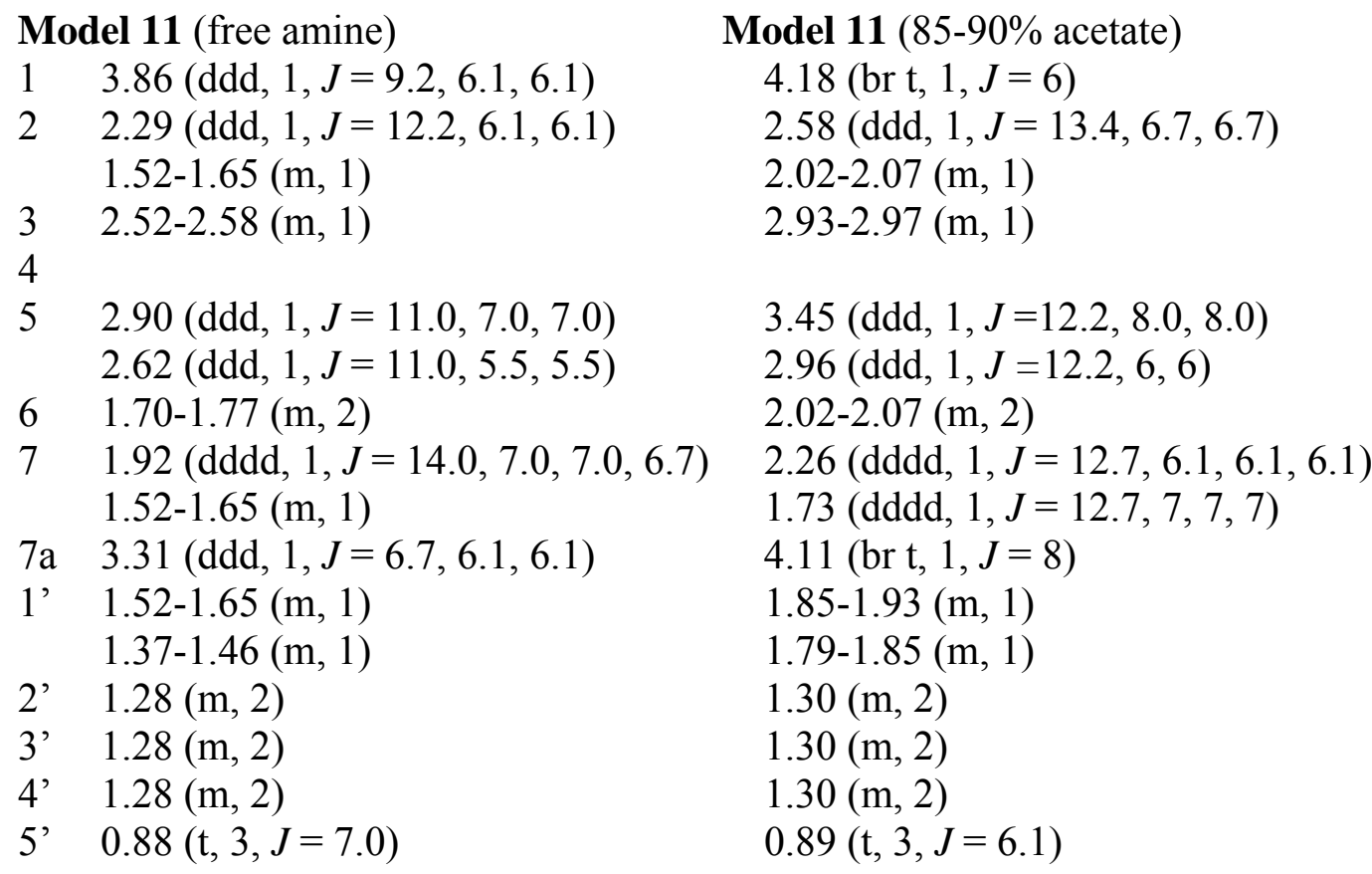

NOE data were obtained for both the free amine and the $85-90 \%$ acetate salt.

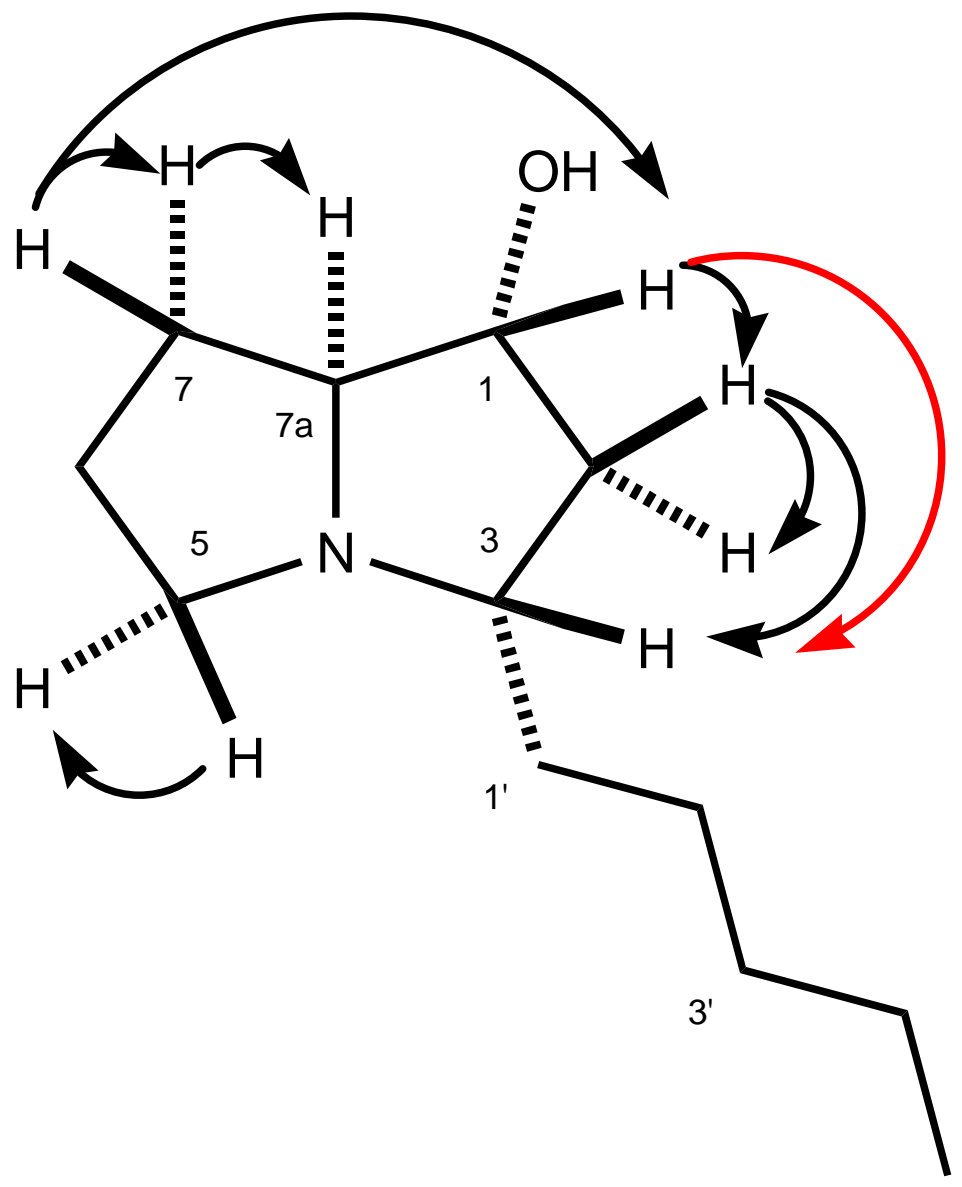




\begin{tabular}{lll} 
& \multicolumn{1}{c}{ Model 16 (free amine) } & Model 16 (acetate salt) \\
1 & $4.17(\mathrm{brt}, 1, J=4.2)$ & $4.33(\mathrm{br} \mathrm{t}, 1, J=4.3)$ \\
2 & $2.08(\mathrm{dd}, 1, J=13.0,5.5)$ & $2.17-2.25(\mathrm{~m}, 1)$ \\
& $1.70-1.73(\mathrm{~m}, 1)$ & $1.91-2.14(\mathrm{~m}, 1)$ \\
3 & $2.85(\mathrm{dddd}, 1, J=11.0,5.5,5.5,5.5)$ & $3.25-3.33(\mathrm{~m}, 1)$ \\
4 & & \\
5 & $3.07(\mathrm{ddd}, 1, J=9.8,4.9,4.9)$ & $3.45(\mathrm{ddd}, 1, J=11.8,8.0,7.3)$ \\
& $2.60(\mathrm{ddd}, 1, J=9.8,7.9,6.1)$ & $2.87(\mathrm{ddd}, 1, J=11.0,5.5,5.5)$ \\
6 & $1.85-1.96(\mathrm{~m}, 2)$ & $1.91-2.14(\mathrm{~m}, 2)$ \\
7 & $1.85-1.96(\mathrm{~m}, 1)$ & $2.17-2.25(\mathrm{~m}, 1)$ \\
& $1.75(\mathrm{dd}, 1, J=11.6,4.2)$ & $1.91-2.14(\mathrm{~m}, 1)$ \\
$7 \mathrm{a}$ & $3.72(\mathrm{br}, 1)$ & $4.43(\mathrm{ddd}, 1, J=8.6,4.3,4.3)$ \\
1, & $1.56-1.66(\mathrm{~m}, 1)$ & $1.85-1.93(\mathrm{~m}, 1)$ \\
& $1.36-1.47(\mathrm{~m}, 1)$ & $1.74-1.89(\mathrm{~m}, 1)$ \\
2 & $1.30(\mathrm{~m}, 2)$ & $1.32(\mathrm{~m}, 2)$ \\
3, & $1.30(\mathrm{~m}, 2)$ & $1.32(\mathrm{~m}, 2)$ \\
4 & $1.30(\mathrm{~m}, 2)$ & $1.32(\mathrm{~m}, 2)$ \\
5, & $0.89(\mathrm{t}, 3, J=7.0)$ & $0.88(\mathrm{t}, 3, J=6.1)$
\end{tabular}

NOE data were obtained for both the free amine and the acetate salt.

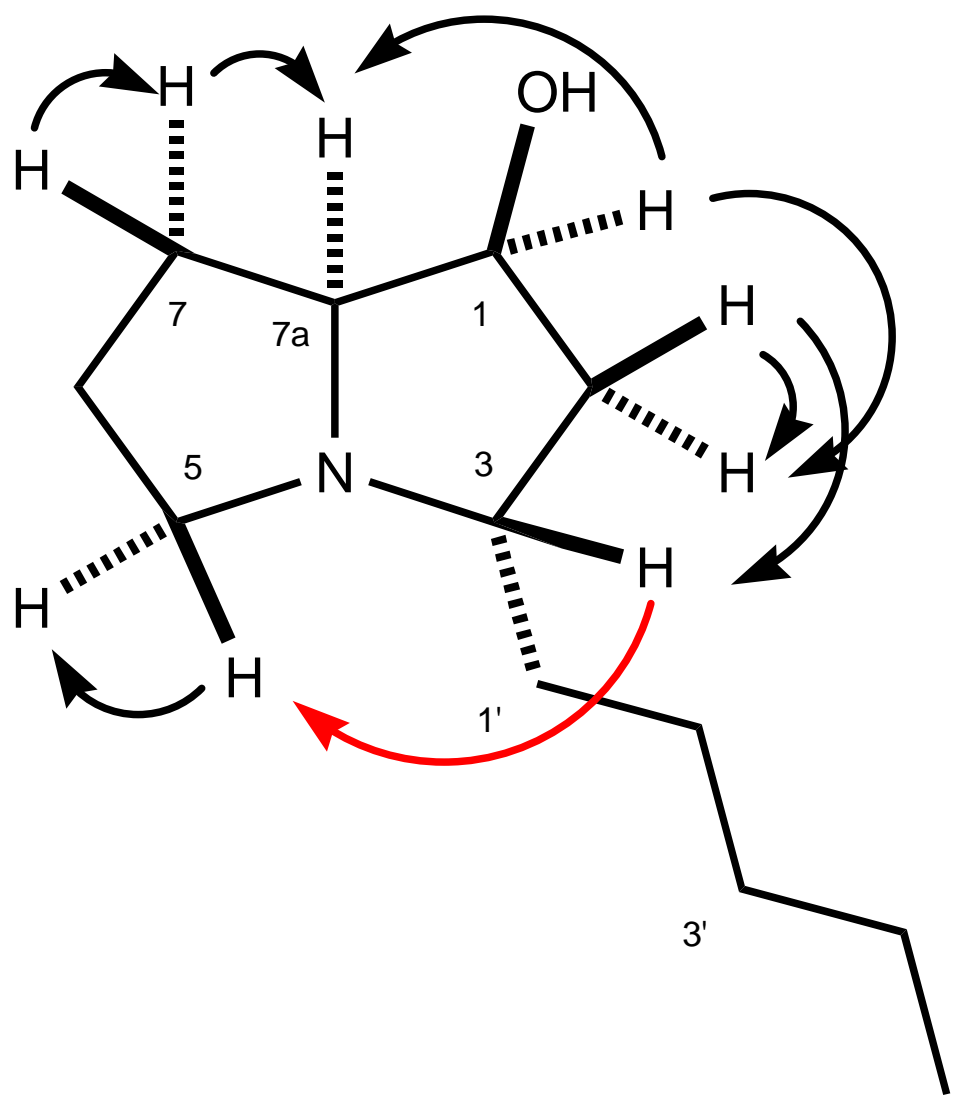

